\title{
Pertumbuhan dan Produksi Tanaman Okra (Abelmoschus Esculentus) Akibat Pemberian POC Terfermentasi MOL dan Pukan Sapi yang Berbeda
}

\section{Growth and Production of Okra (Abelmoschus esculentus) affected by Liquid Organic Fermented with Local Microorganism (LoM) and Different Cow Manure Level}

\author{
Istiyana $^{1 *}$, S. Budiyanto ${ }^{2}$, dan W. Slamet ${ }^{2}$ \\ ${ }^{1}$ Program Studi Agroteknologi, Departemen Pertanian, Fakultas Peternakan dan Pertanian \\ Universitas Diponegoro \\ ${ }^{2}$ Departemen Pertanian, Fakultas Peternakan dan Pertanian, Universitas Diponegoro \\ *Email: isti02yana@gmail.com
}

Diterima 14 Maret 2019 / Disetujui 1 Agustus 2019

\begin{abstract}
ABSTRAK
Keberadaan limbah kulit pisang sangat mengganggu selain dapat membuat lingkungan menjadi kotor juga dapat menimbulkan bau busuk apabila sudah tertimbun lama. Penelitian bertujuan untuk mengkaji pengaruh MOL ikan rucah dalam Pupuk Organik Cair (POC) kulit pisang serta pemberian pupuk kandang sapi terhadap pertumbuhan dan produksi tanaman okra. Rancangan percobaan menggunakan Rancangan Acak Lengkap (RAL) pola faktorial. Faktor pertama adalah pemberian MOL yaitu $0 \mathrm{ml}$ (A0), $5 \mathrm{ml}$ (A1) dan $10 \mathrm{ml}$ (A2). faktor kedua adalah pelakuan penambahan pupuk kandang sapi yaitu 350 g/polybag (P1), 400 g/polybag (P2) dan $450 \mathrm{~g} /$ polybag (P3). Tiap unit perlakuan dengan tiga kali ulangan, parameter yang diamati yaitu jumlah daun, diameter batang, umur berbunga, persentase bunga menjadi buah, diameter buah, jumlah buah, dan berat buah. Data analisis ragam (ANOVA) dan dilanjutkan dengan uji Duncan's Multiple Range Test (DMRT) untuk melihat beda antar perlakuan. Hasil penelitian menunjukkan bahwa peningkatan penambahan dosis MOL pada pemupukan $400 \mathrm{~g}$ N/Polybag menaikan jumlah daun, diameter batang, diameter buah, jumlah buah dan berat buah tanaman Okra. Perlakuan dosis pemupukan pukan sapi $400 \mathrm{~g}$ N/Polybag dengan penambahan MOL $5 \mathrm{ml}$ menghasilkan hasil paling tinggi dibandingkan perlakuan lainnya sehingga dapat digunakan sebagai alternatif paling baik untuk usaha budidaya tanaman Okra.
\end{abstract}

Kata kunci : kulit pisang, ikan rucah

\section{ABSTRACT}

The existence of banana peel waste is very disturbing besides being able to make the environment dirty also can cause a bad smell when it has been buried for a long time. The research aimed to study the effect of Local Microorganism (LoM) trash fish in liquid organic Banana peels and different cow manure fertilizer level on growth and yield of Okra. The experiment was assigned in a completely randomized factorial design with Local Microorganism $(\mathrm{LoM})$ level $(0 \mathrm{ml}, 5 \mathrm{ml}$, and $10 \mathrm{ml})$ as the first factor and cow manure level $(350,400$, and $450 \mathrm{~g} \mathrm{~N} /$ Polybag) as the second factor. Each treatment was repeated three times. Parameters measured were number of leaves, stem diameter, flowering age, percentage of flowers to fruit, fruit diameter, number of fruits, and fruit weight. Data were subjected to ANOVA and followed by Duncan's Multiple Range Test (DMRT). The result showed that cow manure level $400 \mathrm{~g}$ N/Polybag with increasing Local Microorganism (LoM) will increase how many the leaves growth, diameter of stems, diameter of fruits, number of fruits, weight of fruits Okra. Cow manure level $400 \mathrm{~g}$ N/Polybag with adding $5 \mathrm{ml}$ Local Microorganism (LoM) have the highest so can be used as the best alternative for the cultivation of Okra

Keywords : Banana peel, trash fish

\section{PENDAHULUAN}

Tanaman okra merupakan jenis tanaman terna tahunan yang berfamili malvaceae dengan karakteristik morfologi yaitu batang tanaman okra tegak, daun tanaman tersusun spiral, panjang tangkai daunnya mencapai $50 \mathrm{~cm}$. Bunga tanaman 
okra tergolong jenis bunga tunggal yang terletak pada ketiak daun, berwarna kuning dengan panjang tangkai $7 \mathrm{~cm}$. Buah Okra berbentuk silinder atau kapsul menyerupai pyramid dengan panjang 5-35 cm, berdiameter $1-5 \mathrm{~cm}$, buah muda berwarna hijau, ungu kehijauan dan berwarna cokelat apabila sudah matang. Biji okra berwarna hitam dan berbentuk bulat. Produktifitas tanaman okra hijau per tanaman dapat mencapai 84 buah okra (Raditya dkk., 2017).Tanaman okra dapat terus berbunga dalam jangka waktu yang tak tentu berdasarkan jenis varietas, kondisi iklim, dan keadaan tanah yang digunakan pada budidaya tanaman okra. Faktor pemanenan buah okra diketahui dapat menstimulus tanaman untuk terus berbuah sehingga dapat dipanen setiap hari (Ministry of Environment and Forest, 2009). Buah okra dari sisi manfaat bagi kesehatan memiliki kandungan $\alpha$-sellulosa dan hemiselulosa sebanyak $67,50 \%$ yang dapat mengurangi kadar glukosa atau dapat mengatasi diabetes milletus (Desthia dkk., 2015). Banyaknya manfaat yang ada pada buah Okra, menarik minat masyarakat untuk membudidayakan tanaman Okra.

Tanaman Okra membutuhkan nutrisi untuk menunjang pertumbuhannya. Penggunaan Pupuk Organic Cair (POC) maupun pupuk padat merupakan nutrisi hara yang dapat meningkatkan produktifitas tanaman okra. Penambahan MOL (Mikroorganisme Lokal) pada POC berfungsi untuk mempercepat proses pengomposan yang berasal dari bahan organik alami. Sumber bakteri berasal dari lingkungan sekitar seperti nasi basi, ikan busuk, hingga bahan keras seperti kerang (Nisa, 2016). Energy yang digunakan oleh mikroorganisme pengurai untuk kelangsungan hidupnya berasal dari nitrogen. Jumlah nitrogen yang tinggi akan meningkatkan aktivitas mikroba yang merombak senyawa kompleks menjadi senyawa sederhana, menurunkan kandungan $\mathrm{C}$ organic dan meningkatkan senyawa anorganik pada pupuk. Peningkatan jumlah mikroorganisme menyebabkan jumlah kandungan $\mathrm{C}$ organik menjadi berkurang tetapi kandungan $\mathrm{N}$ total menjadi meningkat (Pratiwi dkk., 2013). Nilai C/N rasio yang tinggi pada pupuk apabila diaplikasikan pada tanaman dapat berdampak buruk karena akan terjadi kompetisi hara antara tanaman dan mikroba sehingga tanaman akan mengalami kekurangan unsur hara (Darmawati, 2015). Penurunan aktivitas mikroorganisme akan menurunkan kualitas pupuk (Nasution dkk., 2014). Proses mineralisasi adalah proses terjadinya penguapan $\mathrm{CO}_{2}$ ke udara sehingga menyebabkan jumlah $\mathrm{C}$ menjadi berkurang dan jumlah $\mathrm{N}$ bertambah. Apabila terjadi penurunan $\mathrm{N}$ pada hasil yang diperoleh, hal tersebut disebabkan karena adanya penguapan $\mathrm{N}$ keudara. Unsur N, P, dan K merupakan senyawa dari bahan organik yang terdekomposisi oleh mikroorganisme (Ekawandani dan Kusuma, 2018).

Pupuk padat pada budidaya tanaman okra sering digunakan sebagai pupuk dasar. Pupuk padat berasal dari kotoran sapi memiliki jumlah $\mathrm{N}$ yang cukup tinggi. Pemberian pupuk $\mathrm{N}$ melalui kotoran sapi akan meningkatkan produktifitas tanaman. Peningkatan dosis pupuk kandang dapat meningkatkan kandungan C-Organik, $\mathrm{Ph}$ tanah dan kandungan P-total (Fikdalillah dkk., 2016). Pukan Sapi menunjang pemenuhan unsur hara makro maupun mikro yang disebabkan adanya perbaikan sifat fisik maupun biologis tanah sehingga dapat menyuburkan tanah. Pupuk kandang Sapi dapat meningkatkan jumlah produksi seiring dengan meningkatnya jumlah pemberian dosis pada tanaman (Sriyanto dkk., 2015). Penelitian ini bertujuan untuk mengkaji pengaruh MOL dalam Pupuk Organik Cair (POC) kulit pisang serta pemberian Pupuk Kandang Sapi terhadap pertumbuhan dan produksi tanaman okra.

\section{METODE PENELITIAN}

Penelitian dilakukan pada bulan Septermber-November 2018 di Green House Balai Perlindungan Tanaman Pangan dan Hortikultura (BPTPH) Ungaran, Semarang serta di Laboratorium Ekologi dan Produksi Tanaman, Fakultas Peternakan dan Pertanian, Universitas Diponegoro, Semarang. Materi yang digunakan antara lain benih Okra hijau lokal, kulit pisang, ikan rucah dan pukan sapi.

Penelitian dilakukan dengan persiapan bahan, Pengolahan tanah dengan pemberian pupuk dasar yaitu pukan sapi dengan jumlah sesuai dengan perlakuan. Pemupukan dengan POC kulit 
Pisang dilakukan setiap satu minggu sekali dengan dosis $150 \mathrm{ml} /$ tanaman. Sebelum dilakukan penanaman dibuat lubang tanam. Perpolybag ditanami satu benih tanaman Okra. Benih sebelumnya direndam terlebih dahulu selama $1 \mathrm{x}$ 24 jam. Perawatan dilakukan dengan penyiraman yang dilakukan setiap pagi hari dan penyiangan gulma disekitar tanaman. Panen dilakukan mulai pada minggu keenam setelah tanam, dilakukan selama tiga hari sekali selama satu bulan. Ukuran buah okra yang siap dipanen yaitu sekitar 8-12 cm.

Parameter yang diamati adalah 1). Jumlah daun, 2) diameter batang, 3). Umur berbunga, 4). Persentase berubahnya bunga menjadi buah, 5). Diameter buah, 6) jumlah buah okra per tanaman dan 7) berat buah okra per tanaman. Penelitian menggunakan Rancangan Acak Lengkap (RAL) pola faktorial $3 \times 3$ dengan tiga kali ulangan. Faktor pertama adalah pemberian MOL yaitu $0 \mathrm{ml}$ (A0), 5 $\mathrm{ml}$ (A1) dan $10 \mathrm{ml}$ (A2). faktor kedua adalah pelakuan penambahan pupuk kandang Sapi yaitu 350 g/polybag (P1), 400 g/polybag (P2) dan 450 g/polybag (P3). Analisis data dilakukan secara statistik berdasarkan prosedur analisis ragam (uji F) dan dilanjutkan dengan Duncan's Multiple Range Test (DMRT) pada taraf 5\% untuk melihat beda antar perlakuan.

\section{HASIL DAN PEMBAHASAN}

Tabel 1. Jumlah Daun Tanaman Okra Pada Perlakuan POC Dan Pupuk Kandang Sapi yang Berbeda

\begin{tabular}{lcccl}
\hline \multirow{2}{*}{ POC Kulit Pisang } & \multicolumn{3}{c}{ Dosis Pupuk Kandang Sapi (g N/Polybag) } & \\
\cline { 2 - 4 } POC + MOL 0 ml (A0) & $350(\mathrm{P} 1)$ & $400(\mathrm{P} 2)$ & $450(\mathrm{P} 3)$ & \\
\hline POC + MOL 5 ml (A1) & 8,3 & 7,3 & 7,7 & 7,77 \\
POC + MOL 10 ml (A2) & 8,7 & 9,0 & 8,3 & 8,67 \\
\hline Rata-Rata & 9,0 & 10,3 & 9,3 & 9,53 \\
\hline
\end{tabular}

Peranan unsur hara nitrogen sangatlah penting bagi pertumbuhan dan perkembangan tanaman diantaranya yaitu sebagai pembentuk protein dan klorofil pada tanaman. Hal ini sesuai dengan pendapat Fahmi dkk (2010) yang menyatakan bahwa unsur hara nitrogen memiliki fungsi sebagai penyusun protein, klorofil, asam amino dan banyak senyawa lainnya yang

\section{Jumlah Daun}

Hasil pengamatan jumlah daun pada perlakuan POC dan pukan Sapi yang berbeda tersaji pada Tabel 1. Hasil Duncan's Multiple Range Test (DMRT) menunjukkan bahwa peningkatan dosis MOL pada pemupukan pukan Sapi $400 \mathrm{~g}$ N/Polybag meningkatkan jumlah daun. Hal tersebut disebabkan karena adanya pengaruh pada kandungan bakteri yang ada pada MOL. Peningkatan dosis MOL yang diberikan akan meningkatkan jumlah mikroorganisme sehingga dapat mempengaruhi kandungan $\mathrm{C} / \mathrm{N}$ rasio pada POC. Nilai $\mathrm{C} / \mathrm{N}$ rasio pada POC dengan penambahan MOL $10 \mathrm{ml}$ yaitu sebesar 17,7 dari $\mathrm{C} \%$ sebesar 1,77 dan $\mathrm{N} \%$ sebesar 0,1 yang berarti bahwa terjadi penguraian hara oleh mikroba melalui proses mineralisasi. Proses mineralisasi yang dilakukan oleh mikroorganisme menyebabkan karbon terlepas atau menguap keudara menjadi $\mathrm{CO}_{2}$ sedangkan jumlah $\mathrm{N}$ meningkat. Jumlah nitrogen pada POC yang diberi $10 \mathrm{ml}$ MOL berjumlah paling banyak daripada perlakuan lainnya. Nitrogen berperan dalam perkembangan tubuh mikroorganisme sehingga apabila jumlah nitrogen meningkat menyebabkan penguraian bahan organik lebih cepat (Widarti dkk., 2015). 


\section{Diameter Batang}

Berdasarkan hasil pengamatan diameter batang tanaman Okra pada perlakuan POC dan pukan Sapi yang berbeda tersaji pada Tabel 2 . Hasil Duncan's Multiple Range Test (DMRT) menunjukkan bahwa peningkatan dosis MOL pada pemupukan pukan sapi $350 \mathrm{~g}$ N/Polybag meningkatkan diameter batang yang disebabkan karena adanya pengaruh mikroba dalam MOL ikan rucah. Kenaikan penambahan pemberian MOL akan menambah banyaknya mikroba dalam proses pematangan pupuk. Mikroba didalam MOL ikan rucah yaitu Lactobacillus sp berfungsi untuk memecah senyawa bahan oganik. Bakteri Lactobacillus sp memiliki peran dalam pemecahan bahan organik menjadi asam-asam organik yang dapat diserap oleh tanaman (Fitria dkk., 2015).
Asam- asam organic tersebut berupa asam laktat yang berfungsi dalam mempercepat penguraian serta memproduksi zat asam yang tinggi (Parlinah dan Hidayat, 2017). Mikroorganisme Lokal atau MOL merupakan cairan yang berasal dari bahan alami yang memiliki fungsi sebagai starter pada proses pematangan pupuk organik (Nisa, 2016).

Pertumbuhan mikroba dipengaruhi oleh kandungan $\mathrm{N}$ pada pupuk. Kandungan $\mathrm{N}$ yang sedikit pada POC tanpa MOL. mengakibatkan nilai $\mathrm{C} / \mathrm{N}$ rasio pada $\mathrm{POC}$ menjadi tinggi sehingga aktivitas mikroorganisme dalam mengurai bahan organik menjadi sangat lambat. Kandungan N yang rendah, menurunkan energy pada aktivitas mikroorganisme saat penguraian sehingga proses dekomposisi membutuhkan waktu yang lama (Pratiwi dkk., 2013).

Tabel 2. Diameter Batang (cm) Tanaman Okra pada Perlakuan POC dan Dosis Pupuk Kandang Sapi yang Berbeda

\begin{tabular}{lcccc}
\hline \multirow{2}{*}{ POC Kulit Pisang } & \multicolumn{2}{c}{ Dosis Pupuk Kandang Sapi (g N/Polybag) } & \multirow{2}{*}{ Rerata } \\
\cline { 2 - 4 } & $350(\mathrm{P} 1)$ & $400(\mathrm{P} 2)$ & $450(\mathrm{P} 3)$ & 0,71 \\
\hline POC + MOL 0 ml (A0) & 0,64 & 0,75 & 0,74 & 0,74 \\
POC + MOL 5 ml (A1) & 0,75 & 0,75 & 0,71 & 0,77 \\
POC + MOL10 ml (A2) & 0,76 & 0,78 & 0,76 & \\
\hline Rata-Rata & 0,72 & 0,74 & 0,77 & \\
\hline
\end{tabular}

\section{Umur Berbunga}

Tabel 3. Umur Berbunga (hari) Tanaman Okra pada Perlakuan POC dan Dosis Pupuk Kandang Sapi yang Berbeda

\begin{tabular}{lcccc}
\hline \multirow{2}{*}{ POC Kulit Pisang } & \multicolumn{3}{c}{ Dosis Pupuk Kandang Sapi (g N/Polybag) } & \multirow{2}{*}{ Rerata } \\
\cline { 2 - 4 } & $350(\mathrm{P} 1)$ & $400(\mathrm{P} 2)$ & $450(\mathrm{P} 3)$ & 38,7 \\
POC + MOL 0 ml (A0) & 39 & 40 & 37 & 40,7 \\
POC + MOL 5 ml (A1) & 44 & 40 & 38 & 39 \\
POC + MOL 10 ml (A2) & 40 & 39 & 39,5 & 37,8 \\
\hline Rata-Rata & 41,2 & & \\
\hline
\end{tabular}

Hasil pengamatan umur berbunga tanaman Okra pada perlakuan POC dan pukan Sapi yang berbeda pada Tabel 3. Hasil Duncan's Multiple Range Test (DMRT) menunjukkan bahwa peningkatan penambahan pukan sapi dengan pemberian MOL $5 \mathrm{ml}$ mempercepat umur pembungaan pada tanaman okra yang disebabkan karena meningkatnya jumlah kandungan $\mathrm{P}$ pada setiap kenaikan pemberian dosis pukan sapi. Hal ini sesuai dengan pendapat Fikdalillah dkk (2016) yang menyatakan bahwa peningkatan kandungan $\mathrm{C}$ organik, $\mathrm{pH}$ tanah dan kandungan $\mathrm{P}$ total seiring dengan peningkatan dosis pupuk kandang. Kenaikan $\mathrm{C}$ organik pada tanah menyebabkan nilai 
$\mathrm{C} / \mathrm{N}$ rasio tinggi yang berarti laju dekomposisi cepat dan produksi nitrogen menjadi meningkat (Evanita dkk., 2014).

Proses pembungaan dipengaruhi oleh Unsur hara $\mathrm{P}$ (Fosfor). Hal ini sesuai dengan pendapat Audina dkk (2017) yang menyatakan bahwa Fosfor berperan dalam proses metabolisme energy menghasilkan ATP yang digunakan pada proses pembungaan. Berdasarkan hasil tersebut diketahui bahwa unsur hara pada POC yang diberikan lebih memaksimalkan pertumbuhan vegetatif daripada pertumbuhan generatif. Jumlah daun yang banyak tidak beriringan dengan jumlah bunga yang muncul.

\section{Persentase Bunga menjadi buah}

Hasil pengamatan persentase bunga menjadi buah Okra pada perlakuan POC dan pukan Sapi yang berbeda pada Tabel 4. Hasil Duncan's Multiple Range Test (DMRT) menunjukkan bahwa pada pemupukan dosis pukan sapi dan penambahan MOL pada POC tidak ada perubahan persentase berubahnya bunga menjadi buah pada tanaman Okra. Hal ini diduga karena pembentukan buah terjadi dipengaruhi oleh faktor lingkungan yang mendominasi rangsangan seperti faktor cahaya matahari dan kecukupan air. Tanaman okra termasuk dalam tanaman yang mudah beradaptasi dengan lingkungannya. Hal ini sesuai dengan pendapat Sukprakarn (2009) yang menyatakan bahwa tanaman okra mampu tumbuh dalam segala kondisi tanah dengan suhu $27-30^{\circ} \mathrm{C}$. Tanaman okra tergolong dalam tanaman indeterminasi. Pembungaan awal pada tanaman okra terjadi setelah satu bulan penanaman (Ministry of Environment and Forest, 2009).

Pembentukkan buah dipengaruhi oleh unsur hara Fosfor. P atau Fosfor merupakan senyawa dari bahan organik yang terurai oleh bakteri pada waktu proses dekomposisi. Hal ini sesuai dengan pendapat Ekawandari dan Kusuma (2018) menyatakan bahwa pendekomposisian bahan organik meliputi $\mathrm{P}$ dilakukan oleh bakteri mikroorganisme melalui mineralisasi sehingga mampu diserap oleh tanaman.

Tabel 4. Persentase Bunga Berubah Menjadi Buah Pada Tanaman Okra Pada Perlakuan POC dan Dosis Pupuk Kandang Sapi yang Berbeda.

\begin{tabular}{lcccc}
\hline \multirow{2}{*}{ POC Kulit Pisang } & \multicolumn{3}{c}{ Dosis Pupuk Kandang Sapi (g N/Polybag) } & \multirow{2}{*}{ Rerata } \\
\cline { 2 - 4 } & $350(\mathrm{P} 1)$ & $400(\mathrm{P} 2)$ & $450(\mathrm{P} 3)$ & 87,5 \\
\hline POC + MOL 0 ml (A0) & 92 & 86 & 85 & 94,5 \\
POC + MOL 5 ml (A1) & 100 & 94 & 90 & 95,1 \\
POC + MOL 10 ml (A2) & 100 & 95 & 88,2 \\
\hline Rata-Rata & 97,2 & 91,7 & \\
\hline
\end{tabular}

\section{Diameter Buah}

Hasil pengamatan diameter buah Okra pada perlakuan POC dan pukan Sapi yang berbeda tersaji pada Tabel 5. Hasil Duncan's Multiple Range Test (DMRT) menunjukkan bahwa pada pemupukan pukan sapi dan penambahan dosis MOL pada POC tidak meningkatkan diameter buah secara signifikan. Hal ini diduga karena $\mathrm{C} / \mathrm{N}$ rasio pada masing-masing perlakuan tergolong tinggi yaitu lebih dari 15. Pemberian pupuk yang mengandung $\mathrm{C} / \mathrm{N}$ rasio yang tinggi pada tanaman mengakibatkan terjadinya kompetisi hara antara mikroorganisme yang belum mati dari proses penguraian dengan tanaman yang menyerap hara untuk pertumbuhannya sehingga tanaman akan mengalami kekurangan unsur hara (Darmawati, 2015).

Penguraian bakteri pada POC mempengaruhi jumlah unsur hara POC tersebut. Adapun unsur hara yang berpengaruhi pada produktifitas dan kualitas buah tanaman adalah fosfor (P). Fosfor merupakan salah satu senyawa yang membawa unsur genetik tanaman. Hal ini sesuai dengan pendapat Advinda (2018) yang menyatakan bahwa fosfor adalah senyawa sel pada 
tumbuhan yang memiliki peran dalam proses respirasi dan fotosintesis yaitu sebagai intermediet gula fosfat dan juga sebagai nukleotida yang digunakan untuk proses metabolisme.

Faktor lainnya adalah karena ketersediaan air. Hal ini sesuai dengan pendapat Cahyono (2007) yang menyatakan bahwa pertumbuhan generatif seperti jumlah bunga, jumlah buah, diameter buah dan panjang buah membutuhkan pemberian air yang optimal sehingga dapat meningkatkan produktivitas pada tanaman. Pembelahan sel dalam perkembangan tanaman yang mengakibatkan pertambahan panjang dan diameter buah dipengaruhi oleh kondisi lingkungan seperti kecukupan air pada tanaman (Mochtar dkk, 2018).

Tabel 5. Diameter Buah Okra (cm) pada Perlakuan POC dan Dosis Pupuk Kandang Sapi yang Berbeda

\begin{tabular}{|c|c|c|c|c|}
\hline \multirow[b]{2}{*}{ POC Kulit Pisang } & \multicolumn{3}{|c|}{ Dosis Pupuk Kandang Sapi (g N/Polybag) } & \multirow[b]{2}{*}{ Rerata } \\
\hline & $350(\mathrm{P} 1)$ & $400(\mathrm{P} 2)$ & $450(\mathrm{P} 3)$ & \\
\hline $\mathrm{POC}+\mathrm{MOL} 0 \mathrm{ml}(\mathrm{A} 0)$ & 1,36 & 1,45 & 1,47 & 1,43 \\
\hline POC + MOL 5 ml (A1) & 1,41 & 1,62 & 1,5 & 1,51 \\
\hline POC + MOL 10 ml (A2) & 1,43 & 1,41 & 1,5 & 1,45 \\
\hline Rata-Rata & 1,40 & 1,49 & 1,49 & \\
\hline
\end{tabular}

\section{Jumlah Buah per Tanaman}

Hasil pengamatan jumlah buah Okra pada perlakuan POC dan pukan Sapi yang berbeda tersaji pada Tabel 6. Hasil Duncan's Multiple Range Test (DMRT) menunjukkan bahwa peningkatan pemberian MOL pada pemupukkan dosis pukan Sapi 400 g N/Polybag meningkatkan jumlah buah okra disebabkan karena MOL ikan rucah mengandung bakteri yang berperan dalam proses dekomposisi pupuk. Hal ini sesuai dengan pendapat Fitria dkk (2008) yang menyatakan bahwa salah satu bakteri dalam ikan yang berperan dalam dekomposisi bahan organik yaitu Lactobacillus sp. Bakteri Lactobacillus sp mengubah senyawa bahan organik menjadi asam laktat dan asam asetat. Bakteri asam laktat berperan mempercepat dekomposisi bahan organik (Parlinah dan Hidayat, 2017).

Kualitas pupuk dipengaruhi oleh aktivitas mikroorganisme. Hal ini sesuai dengan pendapat Nasution dkk (2014) yang menyatakan bahwa kualitas pupuk yang rendah dapat disebabkan karena penurunan aktivitas mikroorganisme pada proses fermentasi. Senyawa organik yang didekomposisi oleh mikroorganisme adalah unsur N, P dan K (Ekawandani dan Kusuma, 2018). Batang tanaman yang lebar akan lebih cepat mentransfer hasil fotosintesis sehingga mempengaruhi hasil produksi. Hal ini sesuai dengan pendapat Raditya dkk (2017) yang menyatakan bahwa peningkatan pertumbuhan vegetatif tanaman terutama pada bagian cabang tanaman dapat meningkatkan jumlah buah Okra.

Tabel 6. Jumlah Buah Okra Pada Perlakuan POC dan Dosis Pupuk Kandang Sapi yang Berbeda

\begin{tabular}{lcccc}
\hline \multirow{2}{*}{ POC Kulit Pisang } & \multicolumn{3}{c}{ Dosis Pupuk Kandang Sapi (g N/Polybag) } & \multicolumn{2}{c}{ Rerata } \\
\cline { 2 - 5 } POC + MOL 0 ml (A0) & $350(\mathrm{P} 1)$ & $400(\mathrm{P} 2)$ & $450(\mathrm{P} 3)$ & 11 \\
POC + MOL 5 ml (A1) & 10 & 10 & 16 & 15 \\
POC + MOL 10 ml & 13 & 16 & 14 & 14 \\
(A2) & 12 & 15 & 13,6 & \\
\hline Rata-Rata & & &
\end{tabular}




\section{Berat Buah per Tanaman}

Hasil pengamatan berat buah Okra pada perlakuan POC dan pukan Sapi yang berbeda tersaji pada Tabel 7. Hasil Duncan's Multiple Range Test (DMRT) pada tabel 7 menunjukkan bahwa peningkatan pemberian MOL pada pemupukan pukan sapi $400 \mathrm{~g}$ N/Polybag meningkatkan berat buah okra. Hal ini diduga karena POC dengan pemberian tanpa MOL memiliki $\mathrm{C} / \mathrm{N}$ rasio yang paling tinggi diantara $\mathrm{C} / \mathrm{N}$ rasio perlakuan lainnya yaitu 43,33. Nilai tersebut menunjukkan kualitas POC rendah karena bakteri pada MOL tidak mampu mengurai sempurna bahan organik POC kulit pisang sehingga menyebabkan kurangnya unsur hara pada tanaman. Hal ini sesuai dengan pendapat Darmawati (2015) yang menyatakan bahwa pemberian pupuk yang memiliki kandungan $\mathrm{C} / \mathrm{N}$ rasio yang tinggi pada tanaman akan berdampak buruk pada tanaman karena terjadi persaingan hara antara mikroorganisme pada pupuk dan tanah untuk mendapatkan energy sehingga tanaman kekurangan unsur hara. Perombakan bahan organik melalui mineralisasi dengan sumber energy dari karbon sehingga pada saat proses tersebut kandungan karbon menurun dan jumlah $\mathrm{N}$ meningkat. Apabila jumlah $\mathrm{N}$ menurun disebabkan karena adanya penguapan pada saat proses mineralisasi yang mengakibatkan $\mathrm{C} / \mathrm{N}$ menjadi tinggi (Ekawandani dan Kusuma, 2018).

Tabel 7. Berat Buah Okra (gr) pada Perlakuan POC dan Dosis Pupuk Kandang Sapi yang Berbeda

\begin{tabular}{lcccc}
\hline \multirow{2}{*}{ POC Kulit Pisang } & \multicolumn{3}{c}{ Dosis Pupuk Kandang Sapi (g N/Polybag) } & \multicolumn{2}{l}{ Rerata } \\
\cline { 2 - 4 } & $350(\mathrm{P} 1)$ & $400(\mathrm{P} 2)$ & $450(\mathrm{P} 3)$ & 32,2 \\
POC + MOL 0 ml (A0) & 27,4 & 28,9 & 40,5 & 54,3 \\
POC + MOL 5 ml (A1) & 40,3 & 63,3 & 59,3 & 45,3 \\
POC + MOL 10 ml & 42,8 & 43,4 & 49,8 & \\
(A2) & 36,86 & 45,2 & 49,9 & \\
\hline Rata-Rata & & &
\end{tabular}

\section{KESIMPULAN}

Berdasarkan hasil penelitian dapat disimpulkan bahwa pemberian dosis pukan Sapi sebanyak $400 \mathrm{~g}$ N/Polybag dengan penambahan MOL $5 \mathrm{ml}$ memiliki hasil yang lebih tinggi di bandingkan perlakuan lainnya sehingga dapat menjadi alternatif yang baik untuk usaha budidaya tanaman Okra.

\section{UCAPAN TERIMA KASIH}

Ucapan terima kasih kepada Balai Perlindungan Tanaman Pangan dan Hortikultura (BPTPH) Ungaran yang telah memberikan tempat untuk melakukan riset.

\section{DAFTAR PUSTAKA}

Advinda, L. 2018. Dasar-Dasar Fisiologi Tumbuhan. Deepublish, Yogyakarta.
Darmawati. 2015. Efektivitas berbagai bioaktivator terhadap pembentukkan kompos dari limbah sayur dan daun. J. Dinamika Pertanian 30 (2) : 93-100.

Desthia, U. M., U. Yuniarni dan R. Choesrina. 2015. Uji aktivitas hipoglikemik ekstrak etanol daun okra (abelmoschus esculentus. 1 . moench) pada mencit jantan galur swiss webster dengan metode toleransi glukosa oral. Prosiding penelitian sivitas akademika. 116-120.

Ekawandani, N dan A.A. Kusuma. 2018. Pengomposan sampah organik (Kubis dan Kulit Pisang) dengan menggunakan EM4. TEDC 12(1) : 38-43

Evanita, E., E. widaryanto dan Y. B. Suwasono Heddy. 2014. Pengaruh pupuk kandang Sapi pada pertumbuhan dan hasil tanaman terong (Solanum melongenal) pada pola tanam tumpangsari dengan rumput gajah 
(penisetum purpureum) tanaman pertama. J. Produksi Tanaman 2 (7) : 533-541.

Fikdalillah., Muh. Basir dan I. Wahyudi. 2016. Pengaruh pemberian pupuk kandang Sapi terhadap serapan fosfor dan hasil tanaman sawi putih (Brassica pekinensis) pada entisols sidera. J. Agrotekbis 4 (5) : 491499.

Fitria, Y., B. Ibrahim dan Desniar. 2008. Pembuatan pupuk organik cair dari limbah cair industri perikanan menggunakan asam asetat dan EM4 (Effective Microorganisme 4). J. Sumberdaya Perairan 1 (2) : 23-26.

Fitriani, M. S., Evita dan Jasminarni. 2015. Uji efektifitas beberapa mikroorganisme lokal terhadap pertumbuhan dan hasil tanaman. J. Penelitian Universitas Jambi Seri Sains 17 (2) : 68-74.

Ministy of Environment and Forest (2009). Biology of Okra. India : Department of Biotechnology

Nasution, F. J., L. Mawarni dan Meiriani. 2014. Aplikasi pupuk organik padat dan cair dari kulit pisang kepok untuk pertumbuhan dan produksi sawi (brassica juncea 1.). J. Agroekoteknologi 2 (3) : 1029-1037

Nisa, K. 2016. Memproduksi Kompos \& Mikro Organisme Lokal (MOL). Bibit Publisher, Jakarta.

Parlinah, L dan O. Hidayat. 2017. Mikroorganisme lokal dalam pengomposan pada mutu lobak varietas Greenbow yang dipanen berbeda. J. Paspalum 4 (1) : 40-48.

Pranata, A.S. 2010. Meningkatkan Hasil panen dengan pupuk Organik.PT. AgroMedia Pustaka, Jakarta

Pratiwi, I. G. A. P., I. W. D. Atmaja dan N. N. Soniari.2013. Analisis kualitas kompos limbah pesawahan dengan mol sebagai decomposer. J. Agroekoteknologi Tropika 2 (4) : 195-203.

Raditya, J., E. D. Purbajanti dan W. Slamet. 2017. Pertumbuhan dan produksi Okra (Abelmoschus esculentus 1.) pada level pemupukan nitrogen dan jarak tanam yang berbeda. J. Agro Complex 1 (2) : 49-56.

Sriyanto, D., P. Astuti dan A. P. Sujalu. 2015. Pengaruh dosis pupuk kandang Sapi terhadap pertumbuhan dan hasil tanaman terung ungu dan terung hijau (Solanum melongena L). J. Agrifor 14 (1) : 39-45.

Widarti, B. N., W. K. Wardhim dan E. Sarwono. 2015. Pengaruh rasio $\mathrm{C} / \mathrm{N}$ bahan baku pada pembuatan kompos dari kubis dan kulit pisang. J. Integrasi Proses 5 (2) : 75-80 